Portland State University

PDXScholar

\title{
Modified Design Procedures for Bridge Pile Foundations Subjected to Liquefaction-Induced Lateral Spreading
}

Arash Khosravifar

Portland State University, karash@pdx.edu

Jonathan Nasr

Atlas Geotechnical

Follow this and additional works at: https://pdxscholar.library.pdx.edu/cengin_fac

Part of the Civil Engineering Commons, and the Structural Engineering Commons Let us know how access to this document benefits you.

\section{Citation Details}

Khosravifar, Arash and Nasr, Jonathan, "Modified Design Procedures for Bridge Pile Foundations Subjected to Liquefaction-Induced Lateral Spreading" (2018). Civil and Environmental Engineering Faculty Publications and Presentations. 448.

https://pdxscholar.library.pdx.edu/cengin_fac/448

This Post-Print is brought to you for free and open access. It has been accepted for inclusion in Civil and Environmental Engineering Faculty Publications and Presentations by an authorized administrator of PDXScholar. Please contact us if we can make this document more accessible: pdxscholar@pdx.edu. 


\section{MODIFIED DESIGN PROCEDURES FOR BRIDGE PILE}

FOUNDATIONS SUBJECTED TO LIQUEFACTION-INDUCED

\section{LATERAL SPREADING}

Arash Khosravifar ${ }^{\mathrm{a}}$ and Jonathan Nasr ${ }^{\mathrm{b}}$

${ }^{a}$ Assistant Professor, Department of Civil and Environmental Engineering, Portland State University, Portland, OR, USA;

${ }^{b}$ Staff Engineer, Atlas Geotechnical, Santa Cruz, CA, USA

*Corresponding Author: Arash Khosravifar, Civil and Environmental Engineering

Department, Portland State University, 1930 SW $4^{\text {th }}$ Ave, Portland, OR 97201, Email: karash@pdx.edu 


\title{
MODIFIED DESIGN PROCEDURES FOR BRIDGE PILE FOUNDATIONS SUBJECTED TO LIQUEFACTION-INDUCED LATERAL SPREADING
}

\begin{abstract}
Effective-stress nonlinear dynamic analyses (NDA) were performed for piles in liquefiable sloped ground to assess how inertia and liquefaction-induced lateral spreading combine in long- and short-duration motions. A parametric study was performed using input motions from subduction and crustal earthquakes covering a wide range of durations and amplitudes. The NDA results showed that the pile demands increased due to (a) longer duration shakings, and (b) liquefactioninduced lateral spreading compared to nonliquefied conditions. The NDA results were used to evaluate the accuracy of the equivalent static analysis (ESA) recommended by Caltrans/ODOT for estimating pile demands. Finally, the NDA results were used to develop new ESA methods to combine inertial and lateral spreading loads for estimating elastic and inelastic pile demands.
\end{abstract}

Keywords: Pile; Liquefaction; Lateral Spreading

\section{Introduction}

Past earthquakes indicate that liquefaction-induced lateral spreading is a major cause of collapse of pile foundations and the supported structures. Current design codes require that foundations be designed to sustain both lateral spreading (kinematic) and superstructure loads (inertia) during shaking as shown in Figure 1. However, recommendations vary on how to combine these two loads in design. For example, AASHTO (2014) recommends designing piles for simultaneous effects of inertia and lateral spreading only for large magnitude, and hence long-duration, earthquakes $(\mathrm{M}>8)$. ASCE/COPRI 61 (2014) assumes independent effects of these loads for port facilities, although it recommends evaluating this assumption on a project-specific basis. Caltrans (2012) and ODOT (Ashford et al. 2012) recommend combining 100\% lateral spreading with $50 \%$ inertia. WSDOT (2015), on the other hand, recommends $100 \%$ lateral 
spreading with $25 \%$ inertia.

The Caltrans/ODOT procedures were developed based primarily on a number of centrifuge tests at UC Davis on elastic piles using short-duration shallow crustal earthquakes. It will be described later that the Caltrans/ODOT approach is limited to piles that remain elastic where $50 \%$ of inertia is smaller than the ultimate force in liquefied conditions. In addition, it is shown later that the 50\% multiplier in Caltrans/ODOT method underestimates demands in long-duration subduction earthquakes. The objective of this study is to evaluate the effects of long-duration subduction earthquakes on inelastic deformations of piles subjected to combined inertia and liquefaction-induced lateral spreading. These effects are particularly important in the Pacific Northwest where the expected Cascadia Subduction Zone earthquake (magnitude 8.0 to 9.3 depending on rupture case) is estimated to produce motions with duration as long as 4 minutes.

This paper will, first, present the development of ground motions for two representative sites in Oregon with contributions from the Cascadia Subduction Zone (expected to produce long-duration motions) and crustal sources (expected to produce short-duration motions). Then, the development of a 2-D finite-element dynamic model will be presented. The FE model will be used in a parametric study to perform Nonlinear Dynamic Analyses (NDA) covering a range of ground motions. The pile demands from NDA are used to evaluate current Equivalent Static Analysis (ESA) procedures by Caltrans/ODOT. The NDA results are then used to develop new ESA procedures for design.

The approach adopted in this study was to perform NDA to evaluate the accuracy of ESA procedures. The NDA were performed on a large diameter (2-meter) reinforced concrete (RC) pile in liquefying/nonliquefying soils. The maximum pile head 
displacement was used to represent pile performance in order to compare the results of ESA against those of NDA.

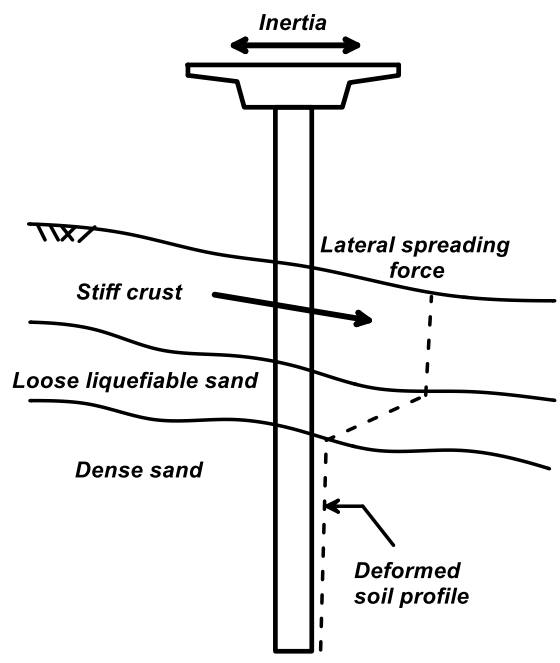

Figure 1. Piles subjected to the combined lateral spreading and inertia

\section{Nonlinear Dynamic Analysis (NDA)}

\section{Finite-Element (FE) Model}

Two-dimensional effective-stress nonlinear dynamic analyses (NDA) were performed in OpenSees Finite-Element (FE) software (Mazzoni et al. 2009). The FE model included three components (Figure 2):

(1) A 2-D soil column was used to simulate the free-field site response. The soil was modeled using Pressure-Dependent-Multi-Yield (PDMY02) constitutive model for sand and Pressure-Independent-Multi-Yield (PIMY) for clay, in conjunction with the 9-4-Quad-UP elements (Yang et al. 2003). The primary focus of the calibration process was to capture liquefaction triggering and post-liquefaction accumulation of shear strains based on semi-empirical correlations by Idriss and Boulanger (2008). Although the 2-D model includes both soil and pile elements, de-coupled conditions were enforced by assigning a large out-of-plane thickness 
to the soil elements. Therefore, the soil column simulated the free-field response. More details on the calibration of the FE model and input parameters are provided in Khosravifar et al. (2014). The ground motions were applied as outcrop motions at the base of the soil column using the compliant-base procedure per Mejia and Dawson (2006).

(2) The RC cast-in-drilled-hole (CIDH) shaft was modeled using fiber sections and nonlinear-beam-column elements. The nonlinear stress-strain behaviors of the reinforcing steel and confined/unconfined concrete were modeled using Steel02 and Concrete02 materials in OpenSees, respectively. This model is capable of capturing the nonlinear behavior of $\mathrm{RC}$ piles and the formation of a plastic hinge at any depth.

(3) The soil-pile interface was simulated using p-y, t-z and q-z soil springs to model lateral, side-friction and end-bearing interface behaviors. The soil spring parameters were obtained based on API (2000). A special type of p-y and t-z springs were used in the liquefied layer (implemented as pyLiq1 and tzLiq1 in OpenSees) where the strength and stiffness of the springs change in proportion to the excess-pore-water pressure ratio in the adjacent soil element. Figure 3 shows how the stiffness and strength of p-y and t-z curves change in the liquefied layer. These models have proven to be effective in capturing the first-order effects of liquefaction during dynamic analyses (Brandenberg et al. 2013). The soil springs were placed at $0.5 \mathrm{~m}$ spacing which was determined based on a sensitivity analysis performed in our previous study (Khosravifar and Boulanger 2010)

The subsurface condition analyzed in this study consisted of a generic three-layer profile: a 5-meter nonliquefying crust with undrained shear strength of $S_{u}=40 \mathrm{kPa}$, overlying a 3-meter loose liquefying sand with normalized SPT blow count of $\left(\mathrm{N}_{1}\right)_{60}=5$, 
overlying a nonliquefying dense sand with $\left(\mathrm{N}_{1}\right)_{60}=35$. The RC pile was 2 meters in diameter with 20-meter embedment and 5-meter height above the ground. The pile head to superstructure connection was free to rotate. The unconfined strength of concrete, $\mathrm{f}_{\mathrm{c}}$, 44.8 MPa. The superstructure dead load was $7 \mathrm{MN}$, corresponding to approximately $5 \%$ $\mathrm{f}^{\prime}{ }^{*} \mathrm{Ag}_{\mathrm{g}}$ (where $\mathrm{Ag}$ is the gross cross section area). The dynamic analyses (NDA) were performed for two conditions: (1) liquefied sloped-ground condition, and (2) nonliquefied level-ground condition where pore-water pressure generation was precluded. In the liquefied sloped-ground condition, a static shear stress was applied to the soil model to simulate a hypothetical $10 \%$ ground slope $(\alpha=0.1)$. The static shear stress was applied such that the horizontal shear stress in each element was $10 \%$ of the vertical effective stress at that depth. The nonliquefied-condition analyses were performed for a level ground site because they were primarily used to estimate inertial demands, which are often estimated in practice using 1-D site-response analysis for level ground sites.

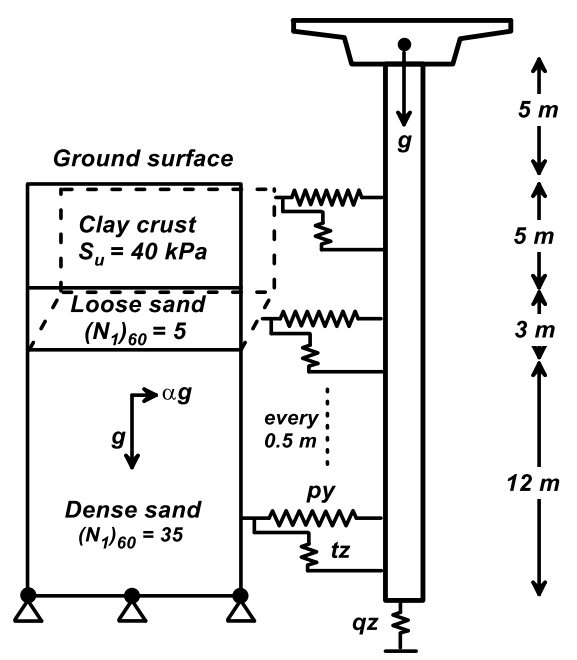

Figure 2. Schematic of the finite-element (FE) model 

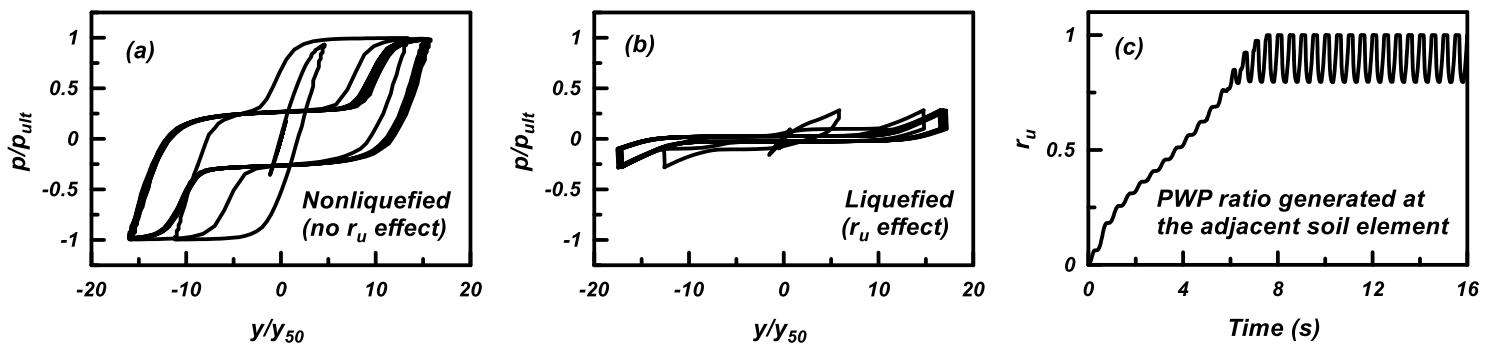

Figure 3. PYLiq1 and TZLiq1 material behavior in (a) nonliquefied conditions, and (b)

liquefied condition due to (c) pore-water-pressure ratio developed in the liquefied layer

\section{Ground motions}

Seismic hazard analyses were conducted for two different sites in Oregon, the coastal city of Astoria and the downtown region of Portland. Based on the 2008 USGS seismic hazard deaggregation tool (Peterson et al. 2008) the seismic hazard in Astoria is almost entirely dominated by a single source, the Cascadia Subduction Zone (CSZ), while the seismic hazard in Portland is controlled by a combination of the CSZ and a nearby crustal fault known as the Portland Hills Fault (PHF). For each site, two design spectra were developed: a 975-year design spectrum per AASHTO (2014) and a risk-targeted maximum considered earthquake $\left(\mathrm{MCE}_{\mathrm{R}}\right)$ spectrum per ASCE 7 (2010). These spectra were developed based on site-specific probabilistic and deterministic seismic hazard analyses (PSHA and DSHA). The PSHA were conducted for two different return periods at each site: a 2475-year return period (ASCE 7-10) and a 975-year return period (AASHTO). The analyses were conducted with the software EZ-FRISK (Fugro 2016), which utilized the 2008 USGS seismic source model (Peterson et al. 2008). To account for the new developments in the ground motion prediction models, we used the ground motion prediction equations (GMPE) and weights based on the 2014 USGS seismic source model (Peterson et al. 2014). The DSHA were performed for the magnitudedistance scenarios shown in Table 1. 
Table 1: Magnitude and distance pairs used for deterministic seismic hazard analyses

\begin{tabular}{|c|c|c|c|}
\hline \multirow{2}{*}{ Site } & Fault & Mw & Distance (km) \\
\hline \multirow{2}{*}{ Portland } & Portland Hills Fault (PHF) & 7.0 & 0.5 \\
\cline { 2 - 4 } & Cascadia Subduction Zone (CSZ) megathrust & 9.0 & 90 \\
\hline \multirow{2}{*}{ Astoria } & Cascadia Subduction Zone (CSZ) megathrust & 9.0 & 19 \\
\hline
\end{tabular}

The target spectra were developed for site class $\mathrm{B} / \mathrm{C}\left(\mathrm{V}_{\mathrm{s}, 30}\right.$ of $\left.760 \mathrm{~m} / \mathrm{s}\right)$ as input for the site-specific NDA. While bridge structures are usually designed using the 975-year spectra per AASHTO (2014), the MCER spectra was developed in this study to investigate the effects of higher intensity motions. The final AASHTO and MCE $\mathrm{R}_{\mathrm{R}}$ spectra for the two sites are shown in Figure 4.

Seven (7) ground motions were selected for each site, considering factors such as fault mechanism, magnitude, shear wave velocity, and source to site distance. In the case of the Portland site and the PHF, the probability of pulse motions was considered based on the work of Hayden et al. (2014). As a result, 2 of the 4 selected crustal motions contained velocity pulses. Each suite of seven motions was scaled to collectively match the respective target spectrum. This was done by scaling the amplitude of time histories such that the geometric mean of the response spectra of the scaled motions closely matched the target spectra. In addition to amplitude scaling, the selected ground motions for the Portland site were spectrally matched to specifically evaluate the effects of motion duration as part of the parametric study. The spectral matching was performed in the frequency domain using RspMatch software (Al Atik and Abrahamson 2010). The characteristics of the selected motions and their response spectra are provided in Appendix A.

The amplitude scaling factors were all within a reasonable range, except for one record (i.e. Talagante (TAL) from 2015 Illapel, Chile earthquake) which was scaled by a factor of 10.2 to match the $\mathrm{MCE}_{\mathrm{R}}$ target spectra at Astoria. While a scale factor of 10.2 is 
larger than what is normally accepted, the record was included in the suite of ground motions due to the lack of recorded subduction records that match our desired magnitude, source-to-site distance, site classification and spectral shape. It was found later that this particular scaled motion resulted in an outlier dynamic response compared to other motions. However, the effect of this outlier data point on our final recommendations is minimized by the use of the geometric mean of the computed responses, as described later in the proposed ESA section.

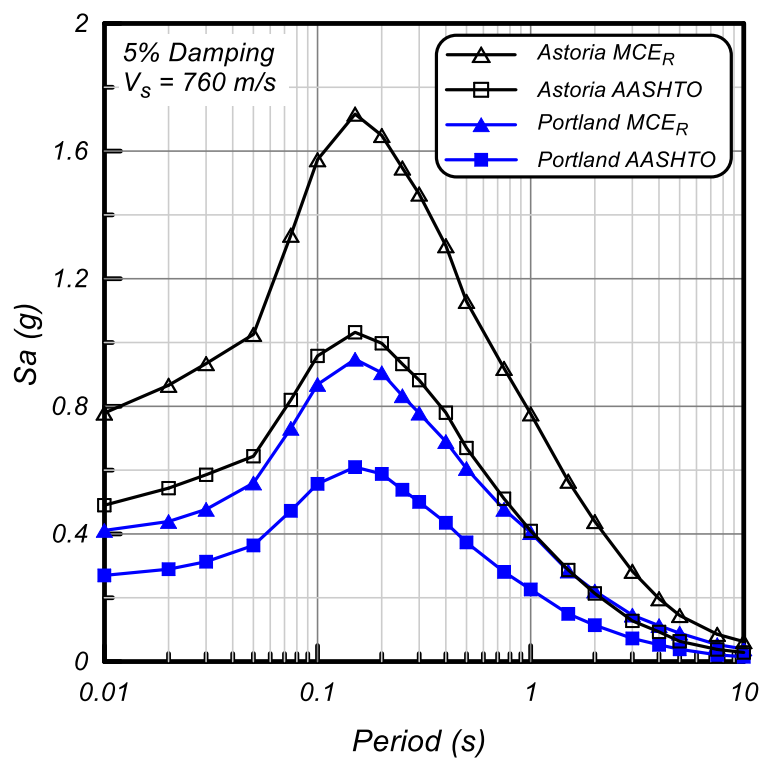

Figure 4. Comparison of Final MCER and AASHTO Target Spectra for Site 1 (Portland) and Site 2 (Astoria)

\section{Nonlinear Dynamic Analysis (NDA) results}

Representative NDA results for one ground motion are shown in Figure 5 as an example. The input motion used in the example is the 2010 Maule earthquake (STL station) scaled to the AASHTO design spectra developed for the Portland site $(\mathrm{PGA}=0.27 \mathrm{~g})$. This is a subduction earthquake with a significant duration, $\mathrm{D}_{5-95}$, of 40.7 seconds. The longduration characteristics of this motion increased the likelihood of inertial and kinematic demands to interact constructively (both in the downslope direction) during shaking. The 
time of maximum pile head displacement $(0.17 \mathrm{~m}$ downslope $)$ is marked by a vertical dashed line in Figure 5. At this time, the superstructure inertia is $75 \%$ of its maximum and the lateral spreading force (crust load) is $70 \%$ of its maximum. Note that at this time liquefaction has already triggered $\left(\mathrm{r}_{\mathrm{u}}=100 \%\right)$, and the lateral spreading load has almost fully mobilized. The relative displacement between soil and pile is 0.35 meters $(0.4$ meters of relative displacement is required to fully mobilize the passive force in the clay crust).

Figure 6 shows aggregated NDA results from all 42 input motions. This figure compares the maximum pile head displacements between liquefied sloped-ground conditions (combined inertial and kinematic demands) and nonliquefied level-ground conditions (inertia only). The fact that all pile demands are larger in the liquefied condition compared to the nonliquefied condition indicates that demands cannot be enveloped by merely accounting for the effects of inertia only or lateral spreading only (i.e. treating them separately). This finding is contrary to the recommendations of MCEER/ATC (2003) that suggests designing piles for the envelope of inertia and kinematics separately. Furthermore, these findings are aligned with the results of other recent studies such as Tokimatsu et al. (2005), Boulanger et al. (2007), Caltrans (2012), and Khosravifar et al. (2014). 

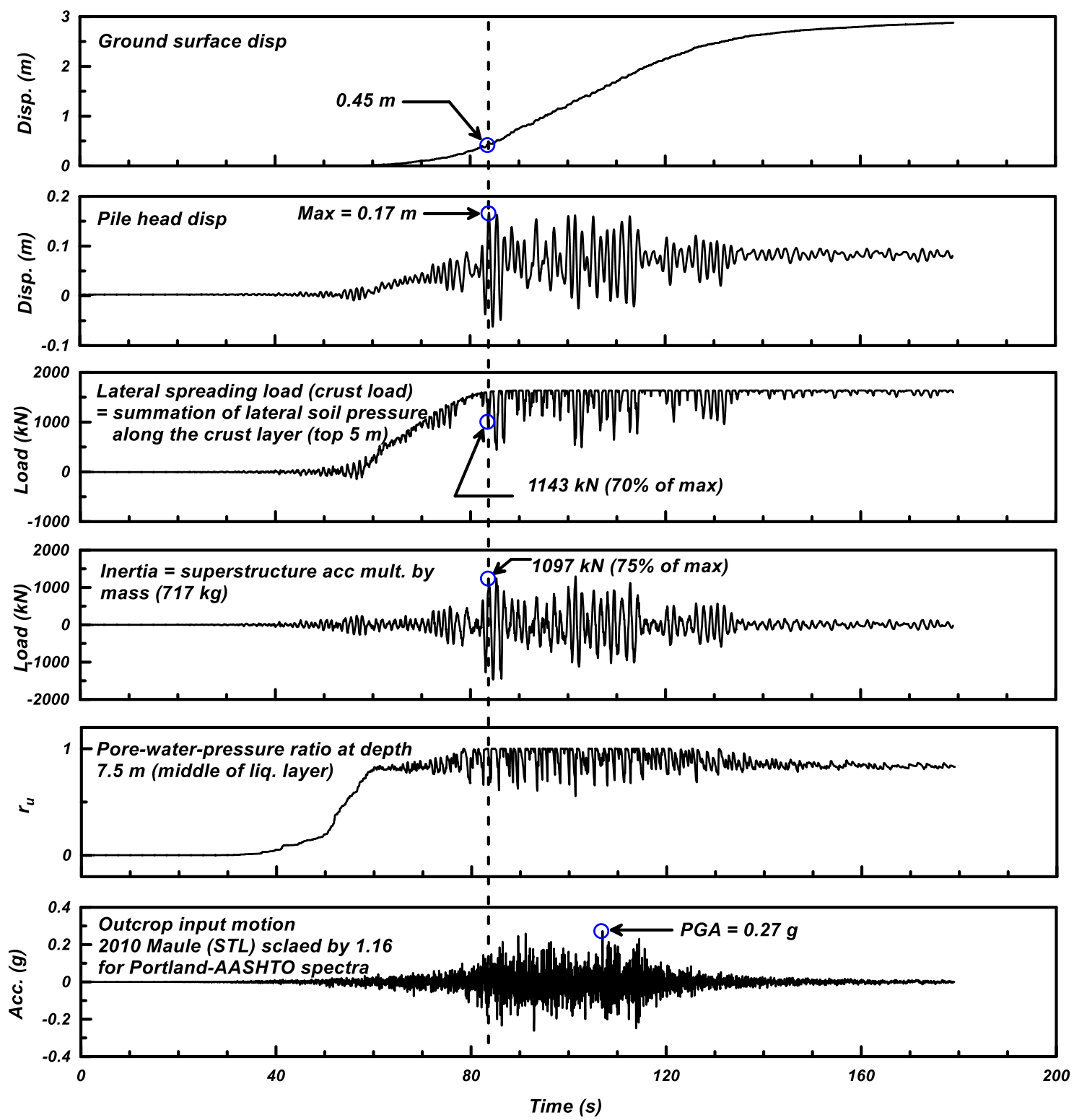

Figure 5. Representative Nonlinear Dynamic Analysis (NDA) results for the 2010

Maule EQ (Station STL) scaled by a factor of 1.16 for the AASHTO design spectrum developed for the Portland site. 


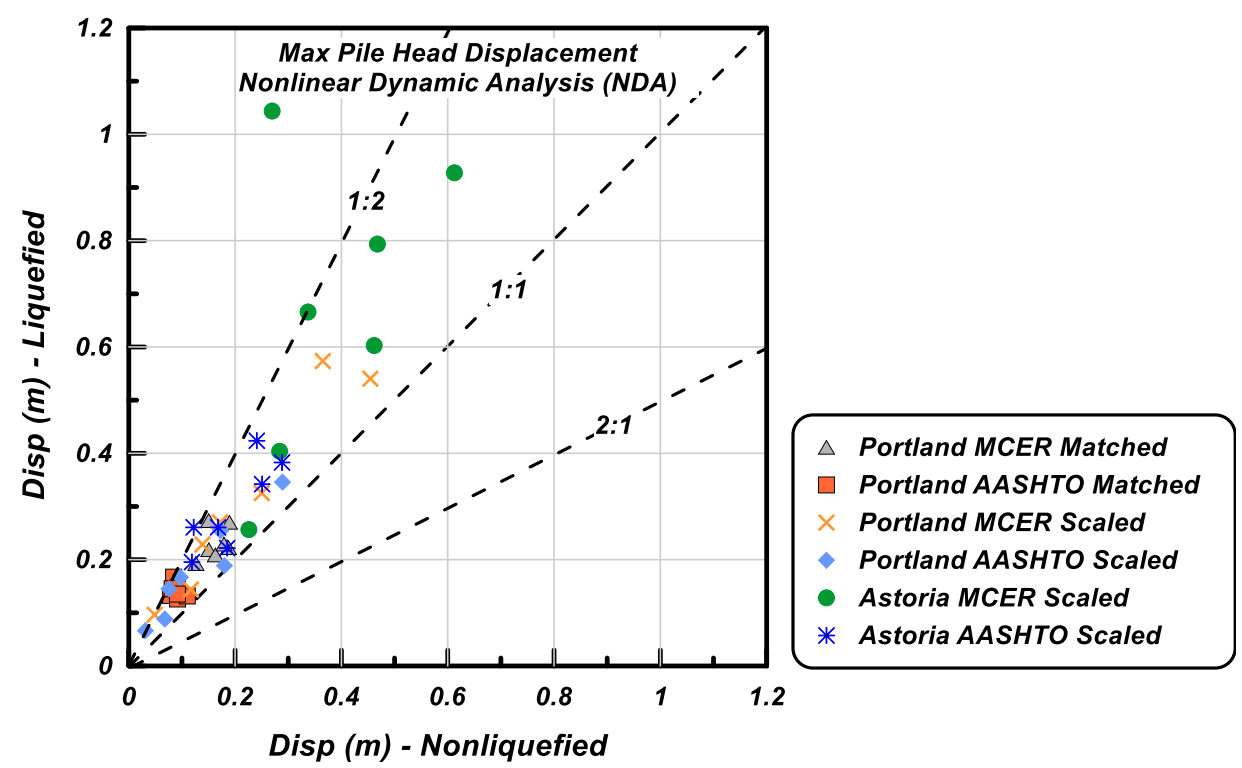

Figure 6. Comparison of maximum pile head displacements in liquefied sloped-ground conditions versus nonliquefied level-ground conditions from nonlinear dynamic analyses (NDA)

\section{Equivalent Static Analysis (ESA)}

The equivalent static analysis (ESA) was performed using the p-y method in LPILE (Ensoft 2016). The accuracy of the ESA method in estimating pile demands was measured by comparing the maximum pile head displacements from ESA to those from NDA. Therefore, it was important that the soil and pile models in the ESA and NDA were comparable. The pile in the ESA was modeled by user-defined nonlinear momentcurvature behavior that replicated the FE model used in the NDA. Similarly, the p-y springs in the ESA model were nearly identical to the ones used in the NDA FE model (i.e. Matlock springs for Clay and O’Neill springs for Sand, per API 2000).

The Caltrans/ODOT ESA method consists of, first, performing pushover analysis for nonliquefied conditions to get the inertial demands, and then performing pushover analysis for liquefied conditions by combining inertial and kinematic demands. The remainder of this section covers the steps involved in performing the Caltrans/ODOT ESA and discusses the accuracy of the method. Once the relative accuracy of the 
Caltrans/ODOT ESA method was evaluated, the NDA results were used to propose an improved ESA method.

\section{Nonliquefied Conditions}

Performing the ESA for nonliquefied condition consists of the following steps: (1) Perform pushover analysis for nonliquefied conditions. This can be done by monotonic application of a lateral load at the column head in a p-y solution software (e.g. LPILE). (2) Estimate the equivalent lateral stiffness and the natural period of the soil-pile system. Caltrans recommends using the first-rebar-yield point to calculate the equivalent stiffness. However, Khosravifar and Boulanger (2012) found that $75 \%$ of the ultimate pushover force better represents the equivalent stiffness; therefore, this method was used in this study. (3) Find the elastic inertia using the elastic design spectrum (5\% damping) developed for the ground-surface in the nonliquefied condition. (4) Use structural load ratio-ductility relationships (i.e. $\mathrm{R}-\mu$-T) to convert elastic inertial demands to inelastic demands. For the bridge structure analyzed here, the natural period of the structure falls in the range in which the equal-displacement assumption can be applied (ATC-32 1996). Figure 7 shows the comparison of the maximum pile head displacements obtained from NDA and those estimated from ESA, both in the nonliquefied condition. This figure shows that the ESA adequately estimates the pile demands in nonliquefied conditions. The residuals between the ESA and NDA results have a standard deviation of 0.15 assuming a log-normal distribution. 


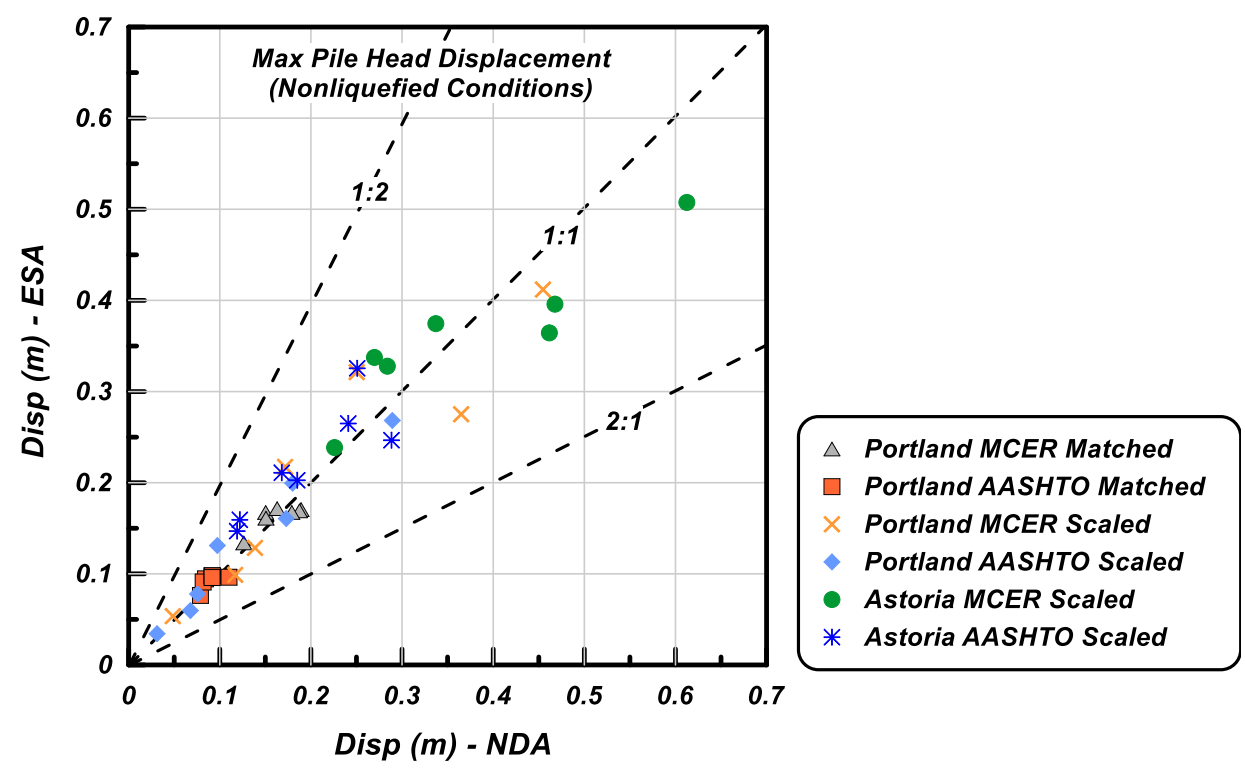

Figure 7. Comparison of maximum pile head displacements in nonliquefied conditions estimated from equivalent static analysis (ESA) and those computed from nonlinear dynamic analysis (NDA)

\section{Liquefied Conditions}

\section{Evaluation of ESA Method by Caltrans/ODOT}

The Caltrans/ODOT method (Caltrans 2012 and Ashford et al. 2012) outlines ESA procedures to estimate pile demands due to liquefaction-induced lateral spreading. The method consists of three primary steps: (1) Estimate kinematic demands by calculating liquefaction-induced lateral spreading displacements. (2) Estimate the inertial load in liquefied conditions that coincides with the kinematic demands by taking $50 \%$ of the maximum inertial load in nonliquefied conditions. (3) Combine $100 \%$ of kinematic demands and $50 \%$ of inertia in ESA.

Estimate Liquefaction-Induced Lateral Spreading. The soil displacements were estimated using the simplified procedures outlined by Idriss and Boulanger (2008). The lateral displacement index (LDI) approach by Zhang et al. (2004) was used with the maximum shear strains by Yoshimine et al. (2006). The factor of safety (FOS) against liquefaction 
in the loose sand layer was found to be 0.1 and 0.15 for the AASHTO and MCER seismic demands at both sites, respectively, indicating that liquefaction will trigger under design level shaking. The free-field lateral spreading displacements were estimated as 1.5 meters for both levels of seismic demands. While the Caltrans/ODOT method allows designers to take advantage of pile-pinning effects to reduce the soil displacements within embankments, the slope in this study was assumed to be infinite and pile-pinning effects were not considered. The soil displacement profile was assumed to be constant through the clay crust and linearly reduced to zero at the bottom of the liquefied layer. The calculated pile head displacement due to the lateral spreading only (i.e. kinematic demand) was 0.04 meters. The ratio of the lateral spreading induced bending moment to the plastic moment of the RC section was $M_{L S} / M_{p}=30 \%\left(M_{p}=30\right.$ MN.m).

Estimation of Inertial Load in Liquefied Conditions. The elastic inertial loads in nonliquefied conditions were multiplied by $50 \%$ per the Caltrans/ODOT guideline which accounts for two main effects: 1) the change in site response due to liquefaction, and 2) the portion of inertia that is likely to coincide with the kinematic loads during the critical cycle. The critical cycle is defined here as the loading cycle during which the pile head displacement is maximum.

Combination of Kinematic and Inertial Demands in a Pushover Analysis for Liquefied Conditions. The pushover analysis was performed by, first, modifying the p-y curves in the liquefied layer. The p-multiplier in the loose liquefiable layer in this study was calculated as 0.05 per Caltrans (2012). The p-multipliers were linearly increased to 1.0 at a distance equal to one pile diameter $(2 \mathrm{~m})$ above and below the liquefying layer to account for the weakening effects of the liquefying layer on the overlying and underlying nonliquefied layers (McGann et al. 2011). Second, the lateral spreading displacements 
were applied to the end-nodes of p-y springs (kinematic demand). Finally, 50\% of the inertial load was applied at pile head. The pushover curve in the liquefied conditions is shown in Figure 8. The pushover curve in the nonliquefied condition is shown for comparison.
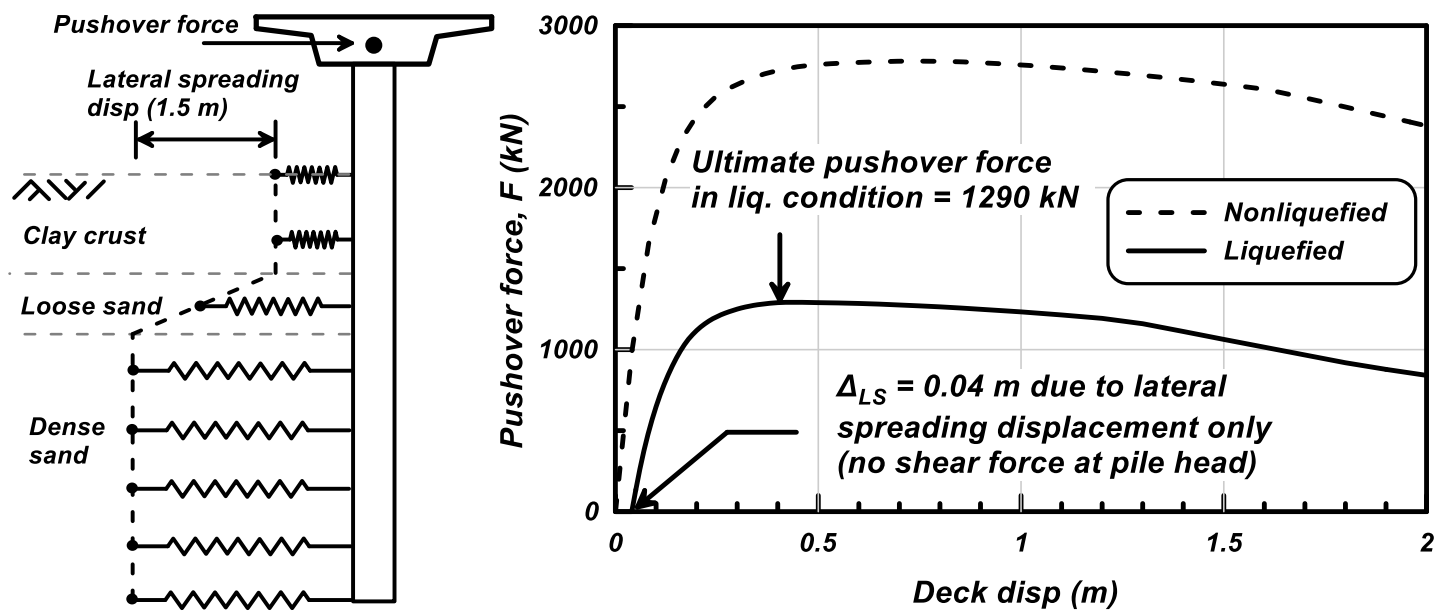

Figure 8. Pushover curve in liquefied and nonliquefied conditions

Comparison of Pile Demands from Caltrans/ODOT ESA Method and NDA Results.

Figure 9 shows the accuracy of the Caltrans/ODOT method in estimating pile demands by comparing pile head displacements estimated from ESA with those computed from NDA. For cases where the inertial load in liquefied conditions $(50 \%$ of inertia in nonliquefied conditions) was smaller than the ultimate pushover load (i.e. $1290 \mathrm{kN}$ ), the Caltrans/ODOT method slightly underestimated pile demands. This is evident from the data points plotted just below the 1:1 line in Figure 9. However, those cases where the inertial load exceeded the ultimate pushover load (inelastic piles) could not be analyzed. This is because the application of inertia in the Caltrans/ODOT method is load-based. These cases are all plotted at 1 meter in Figure 9 for plotting purposes. While most design codes prohibit inelastic deformations in piles under the ground (e.g. ODOT GDM 2014), this performance criterion is costly and sometimes impossible to achieve. This is especially true in cases where a thick non-liquefiable crust overlies a liquefiable layer. In 
the next section, a new ESA method is proposed to estimate inelastic demands in piles, specifically for long-duration earthquakes.

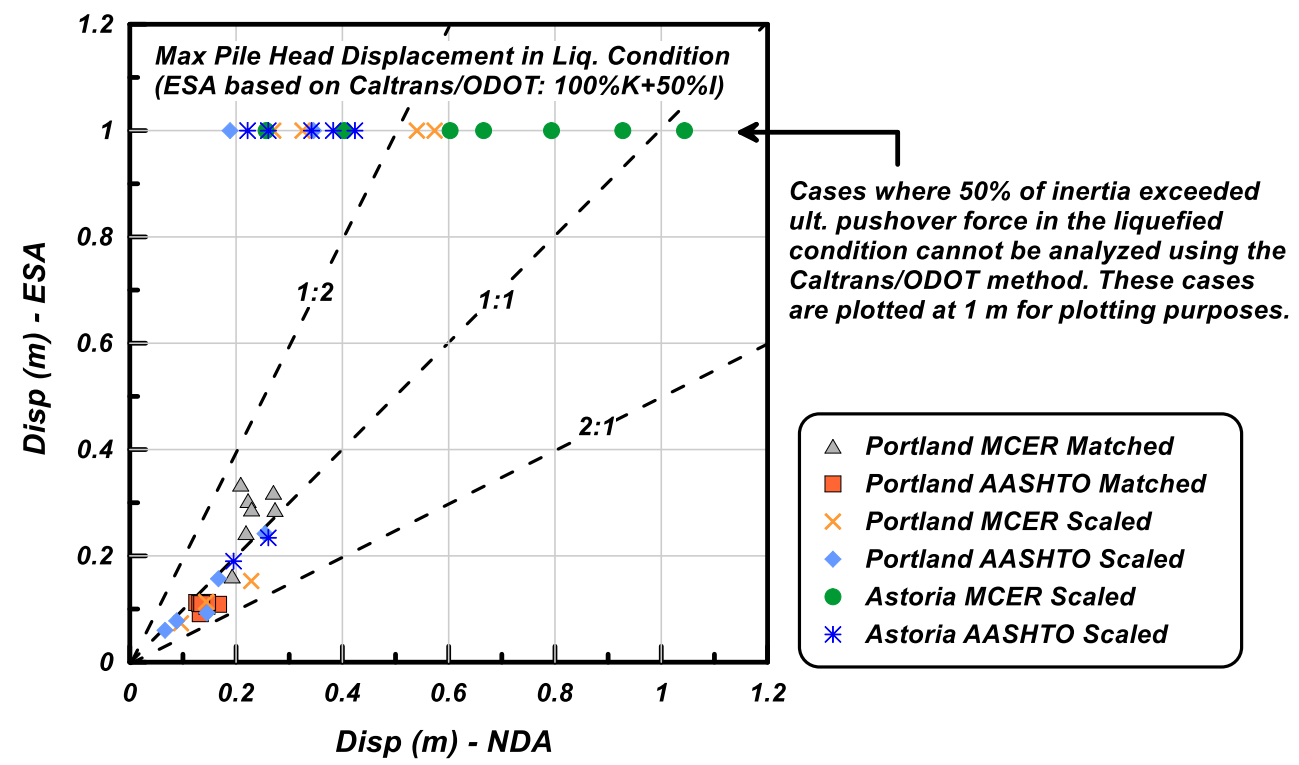

Figure 9. Comparison of the maximum pile head displacement in liquefied condition estimated from the Caltrans/ODOT equivalent static analysis (ESA) method (100\% kinematic $+50 \%$ inertia) with the results of nonlinear dynamic analysis (NDA)

\section{Proposed Equivalent Static Analysis (ESA) Method}

Extension of the ESA to Inelastic Demands. As described in the previous section, the application of the Caltrans/ODOT method is limited to elastic piles, i.e. cases where $50 \%$ of inertia is smaller than the ultimate pushover force in liquefied conditions. To extend the ESA to inelastic piles, a similar approach to the one used in the nonliquefied conditions was adopted in this study and its effectiveness was evaluated against NDA results. The initial stiffness of the liquefied pushover curve was linearized using the point corresponding to $75 \%$ of the ultimate pushover force, from which an elastic displacement demands are calculated. The elastic displacement demands were then converted to inelastic displacement demands following the equal-displacement assumption for long- 
period structures (ATC-32 1996). This process is shown in Figure 10 and formulated in Equation 1:

$$
\Delta_{\text {liq }}=\Delta_{L S}+\frac{\text { (multiplier }) \times(\text { elastic inertia in nonliq. case })}{\text { (initial linear stiffness of pushover curve })}
$$

where, $\Delta_{\text {Liq }}$ is the pile head displacement in the liquefied condition due to the combination of lateral spreading and inertial demands, and $\Delta_{\mathrm{LS}}$ is the pile head displacement due to kinematic demands only. The multiplier in the equation above denotes the fraction of inertia that should be combined with kinematic demands. This multiplier is equal to $50 \%$ in the Caltrans/ODOT method and $60 \% / 75 \%$ in the proposed ESA method as described in the next section.

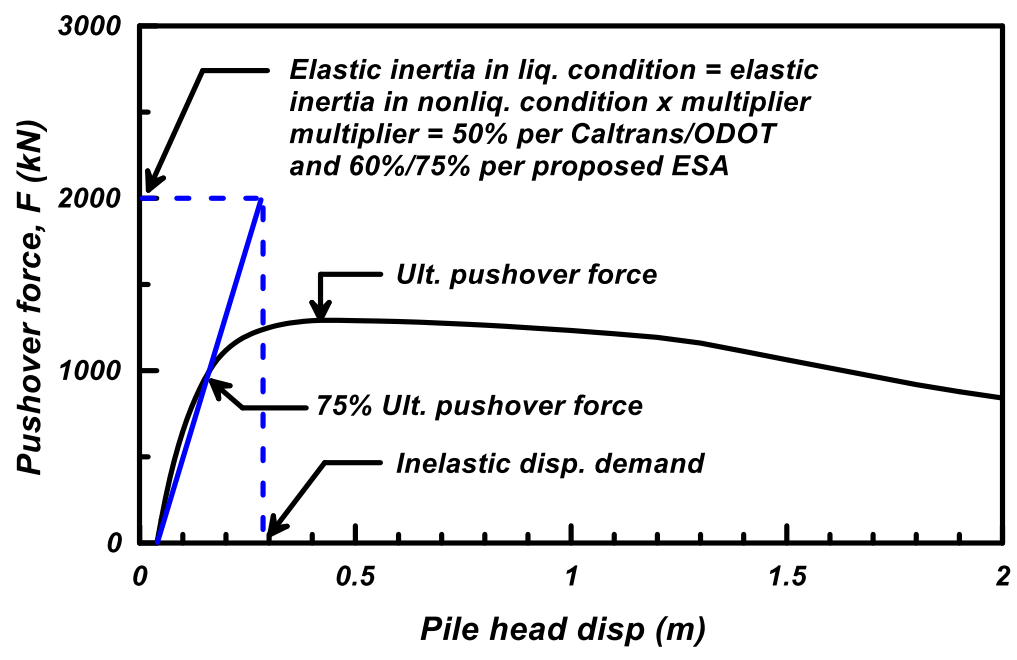

Figure 10. Estimating inelastic demands from liquefied pushover curve using the equaldisplacement assumption for long-period structures

The Choice of Inertia Multiplier. As described earlier, the Caltrans/ODOT method combines $100 \%$ of kinematics with $50 \%$ of inertia. The inertia multipliers were backcalculated from the NDA results using Equation 1 and are plotted in Figure 11. This figure shows the dependence of inertia multiplier to the ground motion duration (D5-95). The geometric mean of the back-calculated multipliers was approximately $60 \%$ for the crustal 
motions (with D5-95 < $20 \mathrm{sec}$ ) and 75\% for the subduction motions (with D5-95 > 20 $\sec )$.

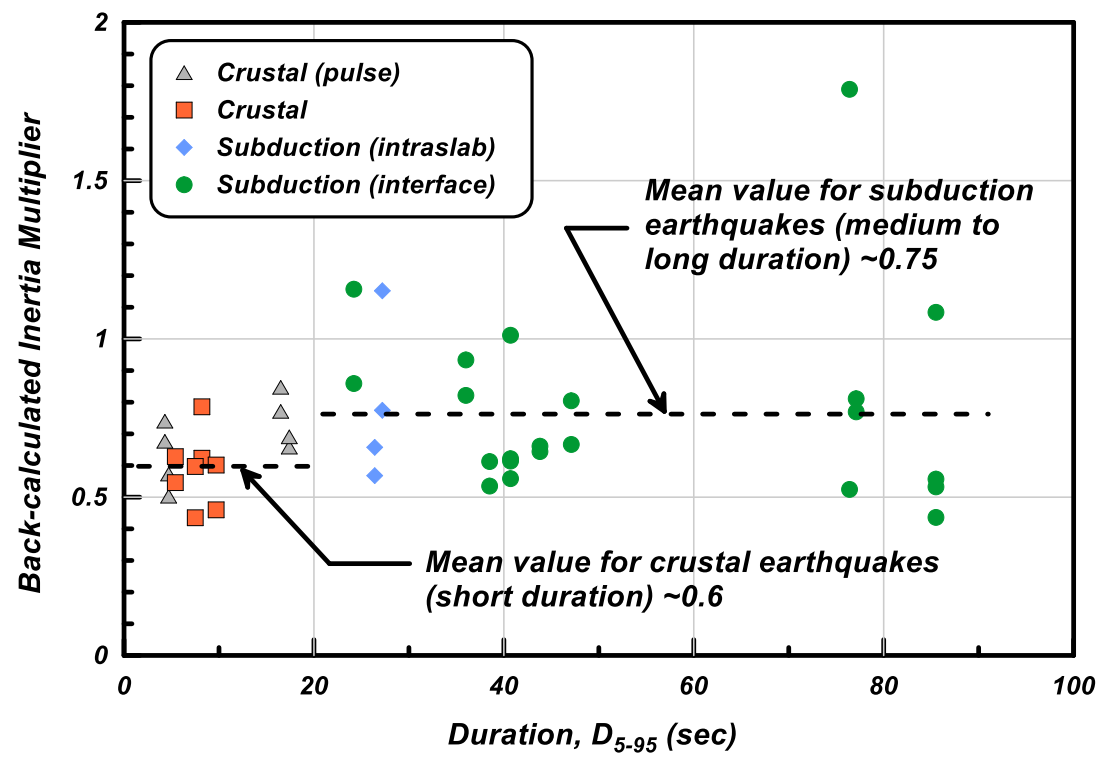

Figure 11. Dependence of the inertia multiplier (back-calculated from dynamic analyses) to ground motion duration (D5-95) for subduction and shallow crustal earthquakes

Proposed ESA. The proposed ESA method consists of the following steps: (1) Apply kinematic demands by imposing soil displacements to the end-nodes of p-y springs to get

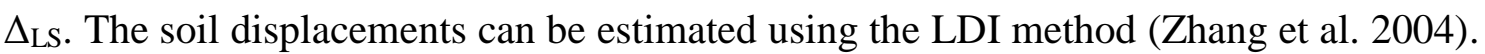
Modify the p-y springs in the liquefied layer, and adjacent layers, using p-multipliers obtained from Caltrans (2012). (2) Estimate the target displacement in the liquefied condition $\left(\Delta_{\text {Liq }}\right)$ from Equation 1. (3) Perform ESA by combining inertia and kinematics as following:

- $100 \%$ Kinematic $+60 \%$ Inertial (for crustal earthquakes with short duration)

- $100 \%$ Kinematic $+75 \%$ Inertial (for subduction earthquakes with medium to long duration) 
Results. Figure 12 shows the comparison of estimated pile demands using the proposed ESA approach against those computed from the dynamic analyses (NDA). This comparison provides a measure of accuracy for the proposed ESA method. The primary improvement of the proposed ESA method over the Caltrans/ODOT method is the adoption of the equal-displacement approach to convert elastic demands to inelastic demands. While the ESA results compare reasonably well with the NDA results for displacements smaller than 0.4 meter, the ESA estimates are unconservative for displacements larger than 0.4 meter. The threshold of 0.4 meter corresponds to the ultimate pushover force in the liquefied condition, beyond which the pile behavior is inelastic (Figure 10). When the displacements are pushed beyond the peak (yield) point on the pushover curve, the pile response becomes very unstable. It is believed that the monotonic nature of the lateral spreading force (crust load) combined with large cyclic inertial loads could excessively, and irrecoverably, deform the pile beyond the yield displacement. Therefore, it is recommended to use the proposed ESA method only for cases where the estimated pile head displacement is smaller than the displacement corresponding to the ultimate pushover force in liquefied conditions (i.e. $0.4 \mathrm{~m}$ in this study).

While the proposed ESA method becomes unconservative for displacements beyond the yield point, the method estimates pile demands reasonably well for elastic piles, including a number of cases that performed well in the NDA but could not be analyzed using the Caltrans/ODOT method (i.e. data points in Figure 9 plotted between 0.2 to 0.4 meter on the horizontal axis and at 1 meter on the vertical axis). Additionally, the proposed ESA method provides a means to identify deformations beyond which the pile response becomes unstable and potentially unconservative. For these cases, an 
equivalent static analysis (ESA) does not accurately predict the pile demands and nonlinear dynamic analysis (NDA) is recommended.

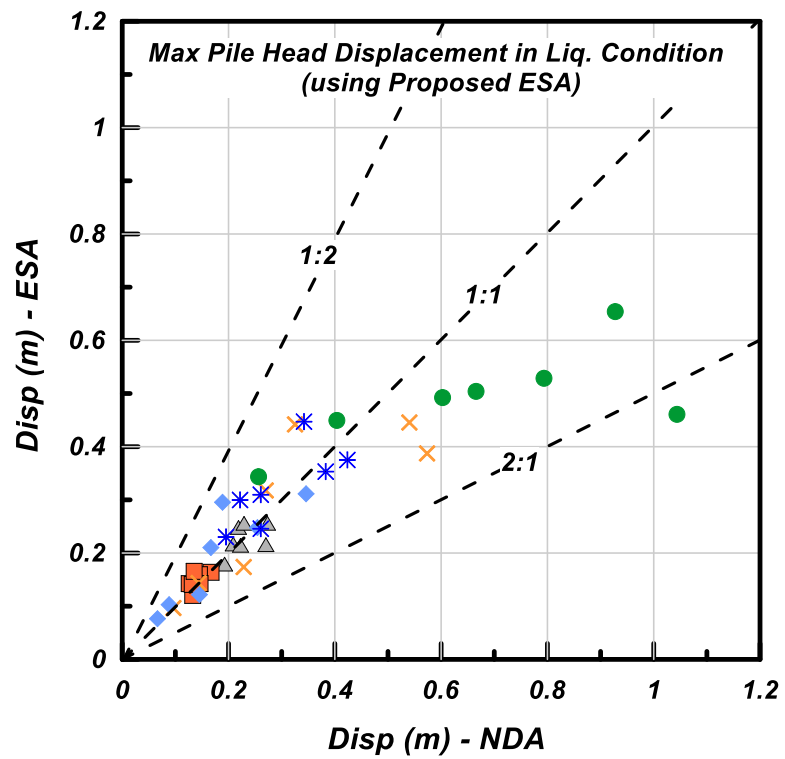

$\triangle$ Portland MCER Matched

$\square$ Portland AASHTO Matched

Portland MCER Scaled

Portland AASHTO Scaled

Astoria MCER Scaled

* Astoria AASHTO Scaled

Figure 12. Comparison of the maximum pile head displacements estimated using the proposed equivalent static analysis (ESA) method with the nonlinear dynamic analysis (NDA) results.

\section{Discussion}

The back-calculated inertia multipliers that are shown in Figure 11 provide a quantifiable measure of how inelastic pile demands increase due to the combination of inertia and kinematics. Two cases are selected to illustrate the effects of motion duration on the inertia multiplier. Case A corresponds to 1992 Cape Mendocino EQ (CPM station) which is a crustal short-duration motion (D5-95 $=5 \mathrm{sec}$ ). Case B corresponds to 2011 Tohoku EQ (MYGH06 station) which is a subduction long-duration motion (D5-95 = $77 \mathrm{sec}$ ). Both motions were spectrally matched to MCER design spectra for the Portland site. Therefore, both motions have similar PGA $(0.5 \mathrm{~g})$ and similar spectral ordinates at the natural period of the structure $(\mathrm{Sa}(\mathrm{T}=1.36 \mathrm{sec})=0.28 \mathrm{~g})$. As a result, both motions result in similar maximum inertial load (2260 kN in MYGH06 and $2350 \mathrm{kN}$ in CPM) and 
similar maximum pile head displacements in the nonliquefied NDA (0.15 $\mathrm{m}$ in MYGH06 and $0.19 \mathrm{~m}$ in CPM). However, the maximum pile head displacement in liquefied conditions is amplified in the case of MYGH06 $(0.27 \mathrm{~m})$ compared to CPM $(0.22 \mathrm{~m})$. This amplification results in a larger inertia multiplier for MYGH06 compared to CPM ( $80 \%$ vs. $60 \%$, back-calculated from Equation 1 using $\Delta_{\mathrm{LS}}=0.04 \mathrm{~m}$ ). The larger inertia multiplier implies that some constructive interaction between inertial and kinematic loads amplifies pile demands, specifically in long-duration motions. This effect is shown on Figure 13 by comparing the moment-curvature response in the plastic hinge for CPM motion (short duration) and MYGH06 (long duration). This figure shows how the incremental yielding in pile amplifies inelastic demands during long-duration motions. The increased inelastic demand is accounted for by using inertia multiplier $=75 \%$ for subduction earthquakes in the proposed ESA method.
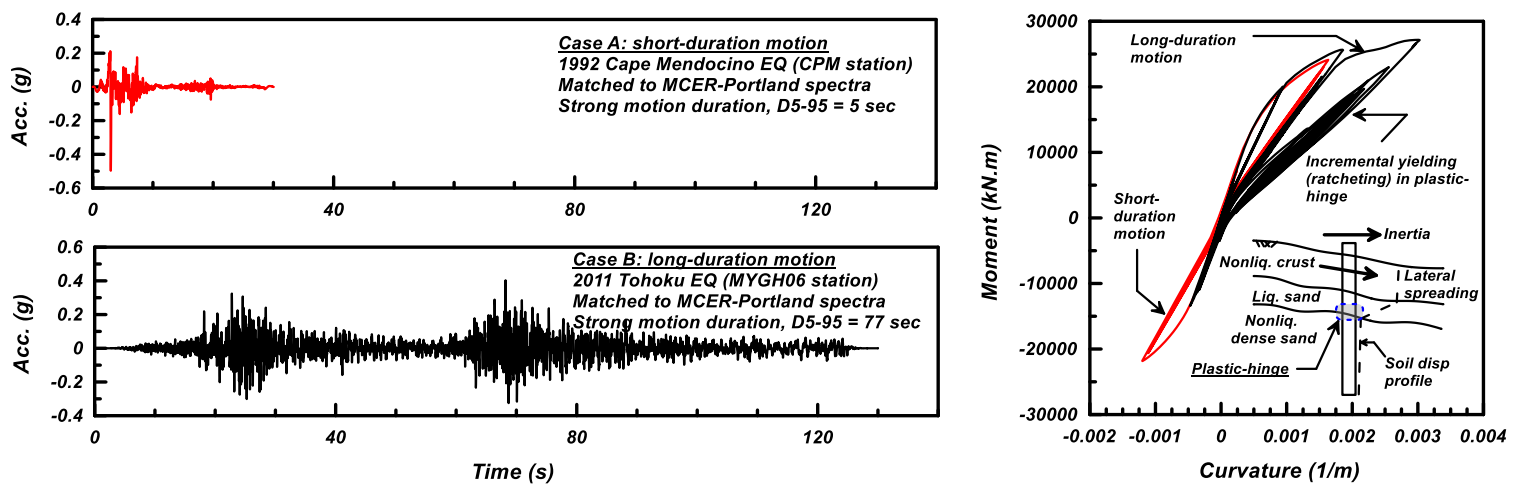

Figure 13. Comparison of moment-curvature behavior in the plastic hinge for a long and short duration motions both spectrally matched to the MCER design spectrum developed for the Portland site

\section{Conclusions}

Effective-stress, nonlinear dynamic analyses (NDA) were performed for a large-diameter (2 meters) RC shaft in sloped liquefying ground. The NDA were performed for a suite of subduction and crustal earthquake motions covering a wide range of durations to evaluate how inertia and lateral-spreading loads combine in short vs. long duration earthquakes. 
The dynamic analyses were performed for both nonliquefiable conditions (without porewater-pressure generation) and liquefied conditions (with PWP generation and liquefaction-induced lateral spreading). The NDA results were used to evaluate current equivalent static analysis (ESA) method by Caltrans/ODOT and develop a new ESA method.

The NDA results showed that pile demands increase in liquefied conditions compared to nonliquefied conditions due to the interaction of inertia (from superstructure) and kinematics (from liquefaction-induced lateral spreading). Comparing pile demands estimated from ESA recommended by Caltrans/ODOT with those computed from NDA showed that the guidelines by Caltrans/ODOT (100\% kinematic combined with $50 \%$ inertia) slightly underestimates demands for piles that remain elastic (where $50 \%$ of inertia is less than the ultimate pushover force in liquefied conditions). A new ESA method was developed to extend the application of the Caltrans/ODOT method to inelastic piles. The inertia multiplier was back-calculated from the NDA results and new multipliers were proposed: $100 \%$ Kinematic $+60 \%$ Inertia for crustal earthquakes and $100 \%$ Kinematic $+75 \%$ Inertia for subduction earthquakes. The proposed ESA compared reasonably well against the NDA results for elastic piles. It also made possible to estimate demands in piles that performed well in the dynamic analyses but could not be analyzed using Caltrans/ODOT method (i.e. inelastic piles that remained below $\mathrm{F}_{\mathrm{ult}}$ on the liquefied pushover curve). However, it was observed that the pile demands became unpredictable for cases where the pile head displacement exceeded the displacement corresponding to the ultimate pushover force in liquefied conditions. Nonlinear dynamic analysis is required for these cases to adequately estimate pile demands.

\section{Acknowledgements}

Funding was provided by the Deep Foundation Institute. The authors appreciate the 
comments by the project advisory board: Dr. Zia Zafir, Dr. Azadeh Bozorgzadeh and Professor Anne Lemnitzer. The authors would also like to thank insightful comments by four reviewers who helped improve the quality of this manuscript.

\section{References}

AASHTO (2014). “Guide Specifications for LRFD Seismic Bridge Design.” Second Edition with 2014 Interim, AASHTO, Washington, D.C.

Al Atik L. and Abrahamson N.A. (2010) An Improved Method for Nonstationary Spectral Matching. Earthquake Spectra: August 2010, Vol. 26, No. 3, pp. 601-617.

American Petroleum Institute (API) (2000). "Recommended Practice for Planning, Designing, and Constructing Fixed Offshore Platforms." API recommended practice 2A-WSD (RP 2AWSD), 21st Edition, API.

ASCE/COPRI 61-14 (2014). "Seismic Design of Piers and Wharves, prepared by the ASCE Standards Comm. on Seismic Design of Piers and Wharves.” ASCE, Reston, VA.

Ashford, S.A., Scott, M.H., and Rayamajhi, D., (2012). "Reducing Seismic Risk to Highway Mobility: Assessment and Design Examples for Pile Foundations Affected by Lateral Spreading”, ODOT Report.

Boulanger, R.W., Chang, D., Brandenberg, S.J., Armstrong, R.J., and Kutter, B.L. (2007). "Seismic design of pile foundations for liquefaction effects." 4th International Conference on Earthquake Geotechnical Engineering, The Netherlands, 277-302. Brandenberg, S.J., Zhao, M., Boulanger, R.W., and Wilson, D.W. (2013). "p-y Plasticity Model for Nonlinear Dynamic Analysis of Piles in Liquefiable Soil.” ASCE JGGE, 139(8), 1262-1274.

California Department of Transportation (Caltrans) (2012). "Guidelines for Foundation Loading and Deformation Due to Liquefaction Induced Lateral Spreading." Sacramento, CA.

Ensoft, (2016). “User's Technical Manual for LPile 2016”

Fugro Consultants Inc., (2016), EZ-FRISK, "Software for Earthquake Ground Motion Estimation., User's Manual

Hayden C.P., Bray J.D., Abrahamson N.A. (2014). Selection of near-fault pulse motions, J. Geotech. Geoenviron. Eng., 140(7): 04014030. 
Idriss, I. M., and Boulanger, R. W., (2008). Soil liquefaction during earthquakes, Monograph MNO-12. Earthquake Engineering Research Institute, Oakland, CA, $261 \mathrm{pp}$.

Khosravifar, A., and Boulanger, R. W., (2010). Inelastic Response of Extended Pile Shafts in Laterally Spreading Ground during Earthquakes. Deep Foundation Institute J. 4, 2, 41-53.

Khosravifar, A., Boulanger, R.W., and Kunnath, S.K. (2014). "Effects of Liquefaction on Inelastic Demands of Bridge Pile Shafts.” Earthquake Spectra, 30 (4), pp, 17491773.

Mazzoni, S., McKenna, F., Scott, M. H., and Fenves, G. L., (2009). Open system for earthquake engineering simulation user manual. University of California, Berkeley.

MCEER/ATC (2003) "Recommended LRFD Guidelines for the Seismic Design of Highway Bridges.” MCEER/ACT 49, Multidisciplinary Center for Earthquake Engineering/Applied Technology Council Joint Venture, University at Buffalo, Buffalo, NY.

McGann, C. R., Arduino, P., and Mackenzie-Helnwein, P., (2011). “Applicability of conventional p-y relations to the analysis of piles in laterally spreading soil.” J. Geotech. Geoenv. Eng. 137, 6, 557-567.

Mejia, L.H., and Dawson, E.M. (2006). "Earthquake Deconvolution for FLAC." Proceedings of Fourth International FLAC Symposium on Numerical Modeling in Geomechanics, Madrid, Spain.

Oregon Dept. of Transportation (2014). Geotechnical Design Manual. Tech. Services Branch, Salem, OR

Petersen, M. D., Frankel, A.D., Harmsen, S.C., Mueller, C. S., Haller, K. M., Wheeler, R.L., Wesson, R.L., Zeng, Y., Boyd, O.S., Perkins, D.M., Luco, N., Field, E.H., Wills, C.J., and Rukstales, K.S. (2008) "Documentation for the 2008 Update of the United States National Seismic Hazard Maps: U.S. Geological Survey OpenFile Report 2008-1128", 61 p

Petersen, M.D., Moschetti, M.P., Powers, P.M., Mueller, C.S., Haller, K.M., Frankel, A.D., Zeng, Yuehua, Rezaeian, Sanaz, Harmsen, S.C., Boyd, O.S., Field, Ned, Chen, Rui, Rukstales, K.S., Luco, Nico, Wheeler, R.L., Williams, R.A., and Olsen, A.H., (2014) "Documentation for the 2014 update of the United States 
national seismic hazard maps: U.S. Geological Survey Open-File Report 2014$1091 ", 243$ p.,

Tokimatsu, K., Suzuki, H., Sato, M. (2005). "Effects of inertial and kinematic interaction on seismic behavior of pile with embedded foundation." Soil Dyn. Earthquake Eng. 25, 753-762.

Washington Deptartment of Transportation (WSDOT) (2015). "Geotech Design Manual.” M 46-03.11, May 2015

Yang, Z., Elgamal, A., and Parra, E., (2003). "Computational model for cyclic mobility and associated shear deformation.” J. Geotech. Geoenviron. Eng, 129, 12, 11191127.

Yoshimine, M., Nishizaki, H., Amano, K., and Hosono, Y., (2006). "Flow deformation of liquefied sand under constant shear load and its application to analysis of flow slide in infinite slope," Soil Dynamics and Earthquake Eng. 26, 253-264.

Zhang, G., Robertson, P. K., and Brachman, R. W. I., (2004). "Estimating liquefactioninduced lateral displacements using the standard penetration test or cone penetration test," J. Geotechnical and Geoenvironmental Eng., ASCE 130(8), 861-71. 


\section{Appendix A: Ground Motions}

\section{A.1. Selected ground Motions}

Table A1: Selected Ground Motions for the Portland, OR Site

\begin{tabular}{|c|c|c|c|c|c|c|c|}
\hline & $\begin{array}{c}2011 \\
\text { Tohoku, } \\
\text { Japan }\end{array}$ & $\begin{array}{c}2010 \\
\text { Maule, } \\
\text { Chile }\end{array}$ & $\begin{array}{l}2001 \mathrm{El} \\
\text { Salvador }\end{array}$ & $\begin{array}{c}1978 \\
\text { Tabas, } \\
\text { Iran }\end{array}$ & $\begin{array}{c}1985 \\
\text { Nahann } \\
\text { i, } \\
\text { Canada }\end{array}$ & $\begin{array}{l}1992 \text { Cape } \\
\text { Mendocin } \\
\text { o, CA }\end{array}$ & $\begin{array}{c}1989 \\
\text { Loma } \\
\text { Prieta, } \\
\text { CA } \\
\end{array}$ \\
\hline Station & $\begin{array}{c}\text { Tajiri } \\
\text { (MYGH0 } \\
6 \text { ) }\end{array}$ & $\begin{array}{l}\text { Cerro } \\
\text { Santa } \\
\text { Lucia } \\
\text { (STL) }\end{array}$ & $\begin{array}{c}\text { Acajutla } \\
\text { Cepa } \\
\text { (CA) }\end{array}$ & $\begin{array}{l}\text { Tabas } \\
\text { (TAB) }\end{array}$ & Site 1 & $\begin{array}{c}\text { Cape } \\
\text { Mendocino } \\
(\mathrm{CPM})\end{array}$ & $\begin{array}{c}\text { Los } \\
\text { Gatos- } \\
\text { Lex. } \\
\text { Dam } \\
\text { (LEX) }\end{array}$ \\
\hline Component & NS & 360 & 90 & $\mathrm{~T} 1$ & 1280 & 00 & 90 \\
\hline Magnitude & 9.0 & 8.8 & 7.7 & 7.35 & 6.76 & 7.01 & 6.93 \\
\hline $\begin{array}{c}\text { Rupture } \\
\text { Distance }(\mathbf{k m})\end{array}$ & 63.8 & 64.9 & $151.8^{*}$ & 2.05 & 9.6 & 6.96 & 5.02 \\
\hline $\begin{array}{l}\text { Vs30 } \\
(\mathrm{m} / \mathbf{s})\end{array}$ & 593 & 1411 & $\begin{array}{c}\text { Intermediat } \\
\mathrm{e} \\
\text { Intrusive } \\
\text { Rock }\end{array}$ & 767 & 605 & 568 & 1070 \\
\hline $\begin{array}{c}\text { Rupture } \\
\text { Mechanism }\end{array}$ & $\begin{array}{l}\text { Subductio } \\
\mathrm{n} \\
\text { (Interface) }\end{array}$ & $\begin{array}{c}\text { Subductio } \\
\mathrm{n} \\
\text { (Interface) }\end{array}$ & $\begin{array}{l}\text { Subduction } \\
\text { (Intraslab) }\end{array}$ & $\begin{array}{c}\text { Crustal } \\
\text { (Reverse } \\
\text { ) }\end{array}$ & $\begin{array}{c}\text { Crustal } \\
\text { (Reverse } \\
\text { ) }\end{array}$ & $\begin{array}{l}\text { Crustal } \\
\text { (Reverse) }\end{array}$ & $\begin{array}{c}\text { Crustal } \\
\text { (Revers } \\
\text { e } \\
\text { Oblique } \\
\text { ) }\end{array}$ \\
\hline $\begin{array}{l}\text { Seed Motion D5-95 } \\
\text { (sec) }\end{array}$ & 85.5 & 40.7 & 27.2 & 16.5 & 7.5 & 9.7 & 4.3 \\
\hline Seed Motion PGA(g) & 0.27 & 0.24 & 0.10 & 0.87 & 1.25 & 1.51 & 0.41 \\
\hline $\begin{array}{c}\text { MCER }_{R} \\
\text { Scale Factor }\end{array}$ & 1.38 & 1.85 & 3.61 & 0.51 & 0.42 & 0.32 & 1.11 \\
\hline $\begin{array}{c}\text { AASHTO } \\
\text { Scale Factor }\end{array}$ & 0.86 & 1.16 & 2.26 & 0.32 & 0.26 & 0.2 & 0.69 \\
\hline
\end{tabular}

*hypocentral distance 
Table A2: Selected Ground Motions for the Astoria, OR Site

\begin{tabular}{|c|c|c|c|c|c|c|c|}
\hline & $\begin{array}{c}2011 \\
\text { Tohoku, } \\
\text { Japan }\end{array}$ & $\begin{array}{c}2011 \\
\text { Tohoku, } \\
\text { Japan }\end{array}$ & $\begin{array}{c}2010 \\
\text { Maule, } \\
\text { Chile }\end{array}$ & $\begin{array}{c}2010 \\
\text { Maule, } \\
\text { Chile }\end{array}$ & $\begin{array}{c}1985 \\
\text { Mexico } \\
\text { City, } \\
\text { Mexico }\end{array}$ & $\begin{array}{c}2015 \\
\text { Illapel, } \\
\text { Chile }\end{array}$ & $\begin{array}{c}2001 \\
\text { Arequip } \\
\text { a, Peru }\end{array}$ \\
\hline Station & $\begin{array}{c}\text { Tajiri } \\
\text { (MYGH0 } \\
6)\end{array}$ & $\begin{array}{c}\text { Matsudo } \\
\text { (CHB00 } \\
2)\end{array}$ & $\begin{array}{c}\text { Cien } \\
\text { Agronomic } \\
\text { as } \\
\text { (ANTU) } \\
\end{array}$ & $\begin{array}{l}\text { Cerro } \\
\text { Santa } \\
\text { Lucia } \\
(\text { STL) } \\
\end{array}$ & $\begin{array}{l}\text { La Union } \\
\text { (UNIO) }\end{array}$ & $\begin{array}{c}\text { Talagant } \\
\mathrm{e} \\
\text { (TAL) }\end{array}$ & $\begin{array}{c}\text { Moquegu } \\
\text { a } \\
\text { (MOQ) }\end{array}$ \\
\hline Component & NS & NS & NS & 360 & N00W & 90 & NS \\
\hline Magnitude & 9.0 & 9.0 & 8.8 & 8.8 & 8.0 & 8.3 & 8.4 \\
\hline $\begin{array}{c}\text { Rupture } \\
\text { Distance }(\mathbf{k m})\end{array}$ & 63.8 & $356.0^{*}$ & 64.6 & 64.9 & $83.9 *$ & 140.9 & 76.7 \\
\hline $\begin{array}{l}\text { Vs30 } \\
(\mathbf{m} / \mathbf{s})\end{array}$ & 593 & $325 * *$ & 621 & 1411 & $\begin{array}{l}\text { Meta- } \\
\text { Andesite } \\
\text { Breccia }\end{array}$ & 1127 & 573 \\
\hline $\begin{array}{c}\text { Rupture } \\
\text { Mechanism }\end{array}$ & $\begin{array}{c}\text { Subducti } \\
\text { on } \\
\text { (Interface } \\
\text { ) }\end{array}$ & $\begin{array}{c}\text { Subducti } \\
\text { on } \\
\text { (Interfac } \\
\text { e) }\end{array}$ & $\begin{array}{r}\text { Subduction } \\
\text { (Interface) }\end{array}$ & $\begin{array}{c}\text { Subducti } \\
\text { on } \\
\text { (Interfac } \\
\text { e) }\end{array}$ & $\begin{array}{r}\text { Subduction } \\
\text { (Interface) }\end{array}$ & $\begin{array}{l}\text { Subducti } \\
\text { on } \\
\text { (Interfac } \\
\text { e) }\end{array}$ & $\begin{array}{c}\text { Subducti } \\
\text { on } \\
\text { (Interfac } \\
\text { e) }\end{array}$ \\
\hline $\begin{array}{l}\text { Seed Motion D } D_{5-95} \\
\text { (sec) }\end{array}$ & 85.5 & 47.1 & 38.5 & 40.7 & 24.2 & 76.4 & 36.0 \\
\hline $\begin{array}{l}\text { Seed Motion } \\
\text { PGA }(\mathrm{g})\end{array}$ & 0.27 & 0.29 & 0.23 & 0.24 & 0.17 & 0.065 & 0.22 \\
\hline $\begin{array}{c}\text { MCEr } \\
\text { Scale Factor }\end{array}$ & 2.35 & 3.00 & 2.75 & 3.00 & 4.50 & 10.20 & 3.10 \\
\hline $\begin{array}{c}\text { AASHTO } \\
\text { Scale Factor }\end{array}$ & 1.40 & 1.60 & 1.80 & 1.80 & 2.75 & 6.50 & 1.90 \\
\hline
\end{tabular}

*hypocentral distance

$* * V s 20$ 


\section{A.2. Acceleration Response Spectra for Scaled and Matched Ground Motions}
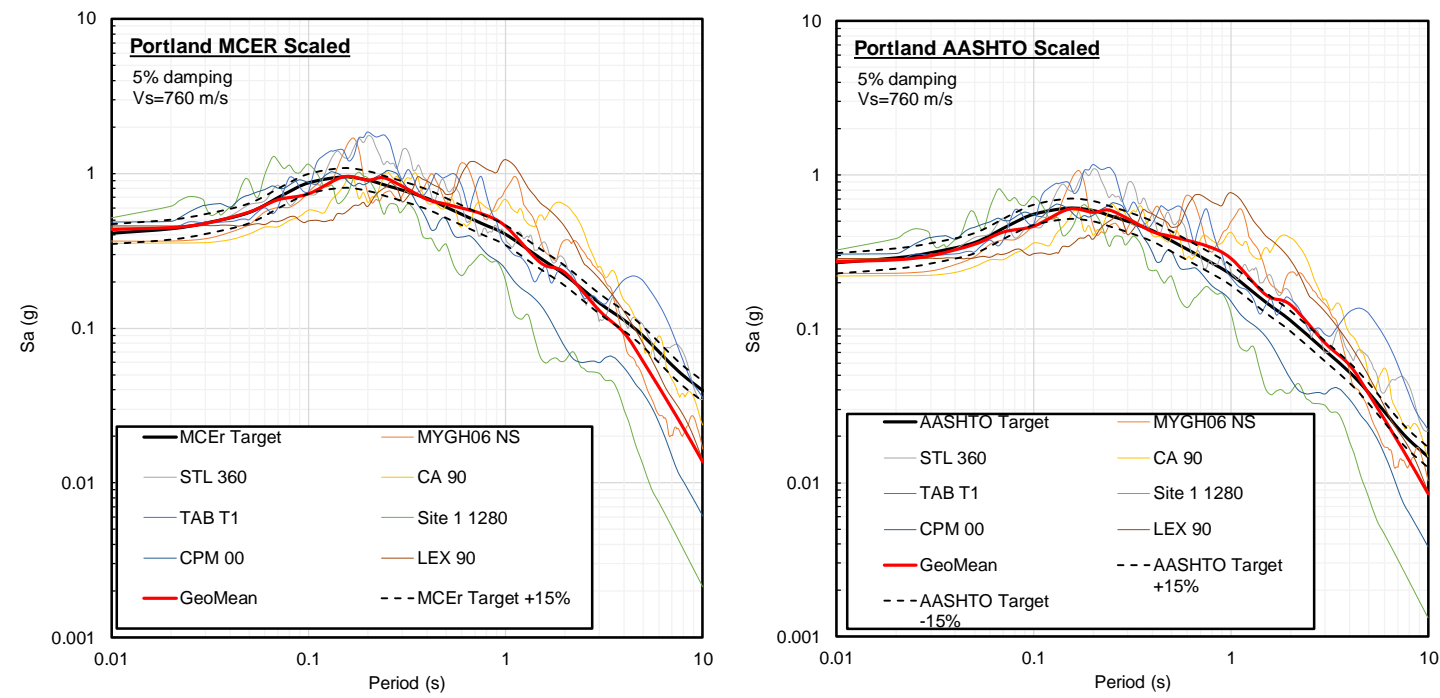

Figure A1. Individual ground motion spectra, scaled to the $\mathrm{MCE}_{\mathrm{R}}$ (left) and AASHTO (right) target spectra for the Portland Site
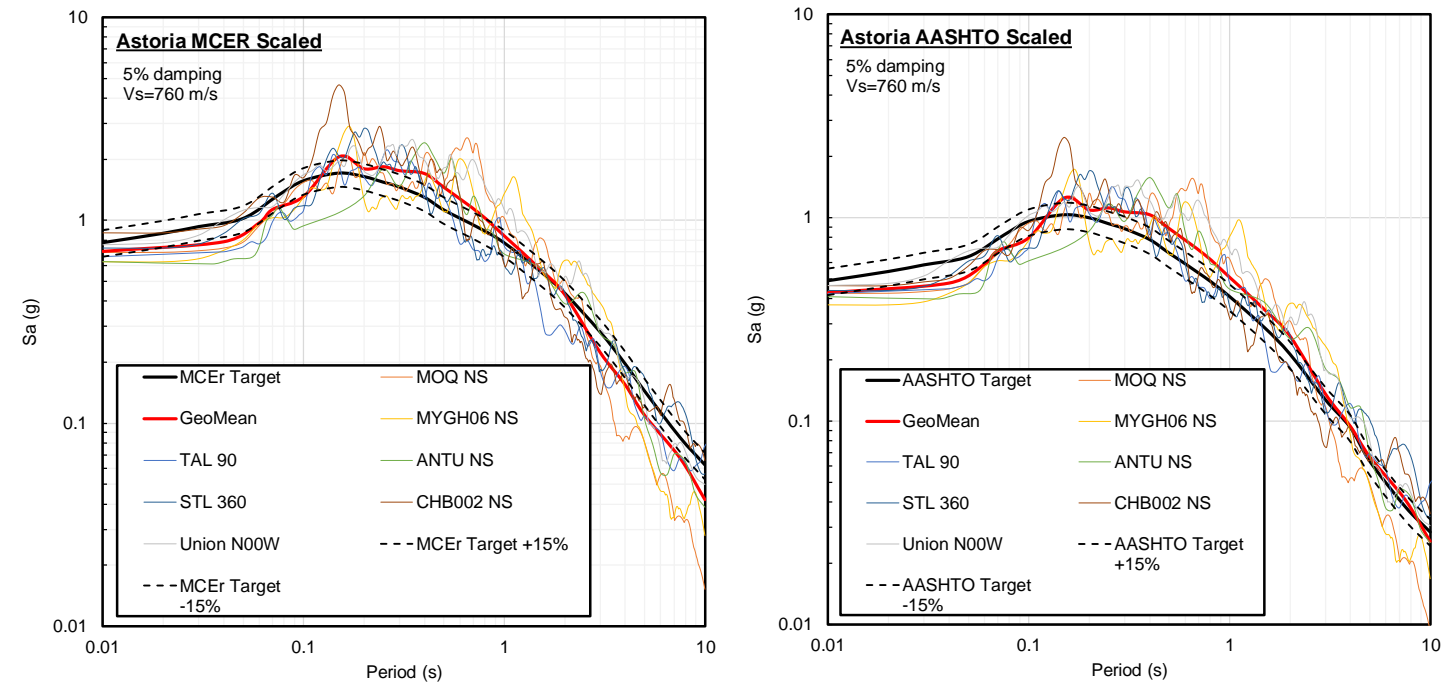

Figure A2. Individual ground motion spectra, scaled to the $\mathrm{MCE}_{\mathrm{R}}$ (left) and AASHTO (right) target spectra for the Astoria Site 

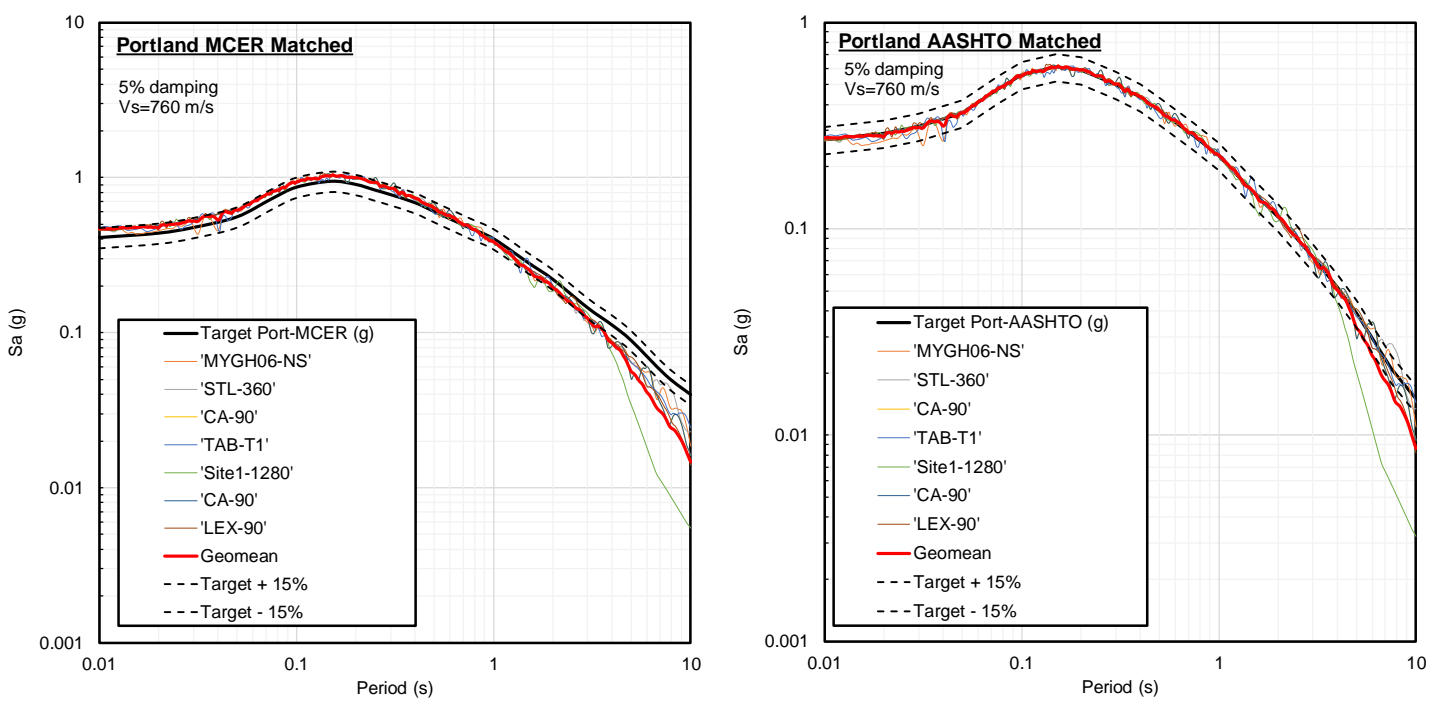

Figure A3. Individual ground motion spectra, spectrally matched to the $\mathrm{MCE}_{\mathrm{R}}$ (left) and AASHTO (right) target spectra for the Portland Site 